\title{
Massage Counterpressure, Massage Effleurage dan Murothal Efektif Menurunkan Nyeri Persalinan Primigravida Kala 1 Fase Aktif
}

\author{
Safinatul Ummah \\ Program Studi Kebidanan Program Sarjana Terapan \\ Sekolah Tinggi Ilmu Kesehatan Indonesia Maju \\ Jln. Harapan No. 50, Lenteng Agung, Jakarta Selatan - Indonesia \\ Email: safinatul.ummah.10@gmail.com
}

\begin{abstract}
A B S T R A C T
Editor: H, Nina

Hak Cipta:

(C)2021 Artikel ini memiliki akses terbuka dan dapat didistribusikan berdasarkan ketentuan Lisensi Atribusi Creative Commons, yang memungkinkan penggunaan, distribusi, dan reproduksi yang tidak dibatasi dalam media apa pun, asalkan nama penulis dan sumber asli disertakan. Karya ini dilisensikan di bawah Lisensi Creative Commons Attribution Share Alike 4.0 Internasional.

Introduction: Labor pain is a physiological condition experienced by the mother during the birth process. The impact of labor pain if left untreated will cause fear and anxiety then it will cause stress and the delivery time will be long. Counterpressure massage, effleurage and murottal are non-pharmacological measures to reduce labor pain. Objectives: The purpose of this study was to determine whether there is an effectiveness of Counterpressure Massage, Massage Effleurage, Murohlah Against the Reduction of Primigravida Stage 1 Labor at BPM " $M$ ".

Method: This research method is quantitative using a quasiexperimental research design. The population in this study were all primigravida mothers in the first phase of labor in the active phase of the Midwife M BPM, amounting to 30 respondents. sample in this study were 30 . The sampling technique uses total sampling because the number of population is relatively small, 30. The instrument used is a face scale sheet. Data processing using computerized, with univariate and bivariate data analysis.

Result: T-dependent massage counterpressure test results obtained pvalue $=0,000<0.05$, massage effect p-value $0.001<0.05$, and for murothal p-value $0.010<0.05$. Based on the results of the study it can be concluded that the counterpressure, effleurage and murothal at BPM Midwife M affect labor pain. With this research, it is expected that BPM will further increase efforts to reduce the level of pain with this research.

Conclution: It is expected that in midwives $M$ midwives will perform counterpressure massage treatments for each delivery patient so as to improve the quality of service.
\end{abstract}

Keyword: Massage Counterpressure, Massage Effleurage, Murothal, Labor Pain. 


\section{SIMFISIS Jurnal Kebidanan Indonesia}

Volume 01, Nomor 01, Agustus 2021

\section{Pendahuluan}

Melahirkan adalah proses yang normal dan alami walaupun untuk melakukan proses melahirkan secara normal membutuhkan persiapan yang matang secara fisik, mental, dan spiritual. Proses melahirkan adalah saat yang ditunggu-tunggu oleh ibu hamil, usai berjuang selama 9 bulan pada masa kehamilannya. ${ }^{1}$ Melahirkan memang selalu disertai dengan rasa sakit, rasa sakit yang terjadi disebabkan karena adanya aktivitas yang sangat besar didalam tubuh untuk mengeluarkan bayi dari dalam Rahim, otot-otot rahim akan berkontraksi membantu bayi keluar dari rahim. ${ }^{1}$ Kelahiran bayi merupakan pristiwa yang penting dan merupakan hal yang paling ditunggu bagi seorang ibu dan keluarga. Ketika persalinan dimulai, peran ibu adalah melahirkan bayinya, Peran petugas kesehatan adalah memantau persalinan untuk memantau persalinan untuk mendeteksi dini adanya komplikasi disamping itu bersama keluarga memberikan bantuan dan dukungan pada ibu bersalin. ${ }^{2}$

Menurut WHO (World Health Organization) memperkirakan setiap tahun terjadi 210 juta kehamilan diseluruh dunia dengan 20 juta perempuan mengalami kesakitan seperti rasa nyeri, dan rasa takut. Menurut laporan WHO pada tahun 2014 angka kematian ibu didunia yaitu sebesar 289.000 jiwa dan asia tenggara menjadi negara ke 4 yang memiliki jumlah aki terbesar yaitu sebesar 16.000 jiwa. $^{3}$ Pada primipara lama persalinan pada kala I mempunyai durasi yang lebih lama dibandingkan dengan multipara, dimana lama persalinan kala I pada primipara sekitar 13-14 jam sedangkan pada multipara sekitar 7 jam. Partus lama dapat dipengaruhi oleh kondisi psikologis ibu yang meliputi presepsi ibu pada rasa nyeri saat persalinan.

Berdasarkan United Nation Population Fund (UNFPA) jumlah kelahiran (fertilitas) di indonesia pada tahun 2019 mempunya pergerakan angka kelahiran relatif stabil. Jumlah kelahiran sedikit menurun dari 2015-2020, setelah ituh mulai naik kembali hingga 2029.pada 2045 jumlah kelahiran di prediksi sebanya 4,5 juta jiwa. Saat ini Provinsi Jawa Barat merupakan provinsi dengan jumlah penduduk terbesar di Indonesia, yaitu 48,4 juta jiwa pada tahun 2018 (proyeksi penduduk indonesia 2015-2045), dengan sex ratio 102,83 dengan Laju Pertumbuhan Penduduk (LPP) 2016-2017 sebesar 1.39. angka kelahiran menurut kelompok umur adalah banyaknya kelahiran per 1.000 wanita dari golongan umur tertentu. $^{4}$

Nyeri merupakan pengalaman yang tidak menyenangkan yang dirasakan seseorang terhadap stimulus tertentu dan tidak dapat dibagi kepada orang lain. Nyeri adalah pengalaman sensorik dan emosional yang dapat menyenangkan akibat kerusakan jaringan yang nyata dan potensial. Nyeri merupakan mekanisme pertahanan tubuh yang timbul, bila ada jaringan rusak dan hal ini akan menyebabkan individu bereaksi dengan cara memindahkan stimulus nyeri. ${ }^{5}$ Rasa nyeri pada persalinan terjadi karena kontraksi uterus dalam kala pengeluaran janin. Dalam persalinan normal, saat awal persalinan sampai pembukaan lengkap akan berlangsung 12-18 jam, dilanjutkan pengeluaran janin sampai pengeluaran plasenta. Rasa nyeri ini dipengaruhi oleh kelelahan, keletihan, kecemasan, dan rasa takut yang akan menyebabkan peningkatan rasa nyeri. ${ }^{5}$ Pengalaman rasa nyeri persalinan berbeda antara satu wanita dengan wanita lain dan persalinan pertama dengan persalinan berikutnya pada wanita yang sama. ${ }^{6}$

Nyeri persalinan menghasilkan nilai psikis dan refleksi fisik. Nyeri persalinan memberikan gejala yang dapat diidentifikasi seperti pada sistem syaraf simpatis yang dapat terjadi mengakibatkan perubahan tekanan darah, nadi, respirasi, dan warna kulit. Ekspresi sikap juga berubah meliputi peningkatan kecemasan, mengerang, menangis, gerakan tangan (yang menandakan nyeri) dan ketegangan otot yang sangat diseluruh tubuh. Rasa nyeri apabila tidak ditangani akan menimbulkan rasa takut dan cemas kemudian akan menimbulkan stres serta meningkatkan produksi hormon adrenalin yang 


\section{SIMFISIS Jurnal Kebidanan Indonesia}

Volume 01, Nomor 01, Agustus 2021

mengakibatkan penyempitan pada pembuluh darah dan mengurangi aliran darah yang akan membawa oksigen kerahim sehingga kontraksi mengalami penurunan serta waktu persalinan menjadi panjang. ${ }^{6}$

Banyak metode untuk kmengurangi rasa nyeri saat menjalani proses persalinan dengan nyaman dan tidak membuat trauma yaitu persalinan dengan teknik ILA (Intrathecal Labor Analgesia), teknik epidural dan lain-lain. ${ }^{6}$ Rasa nyeri pada kala I disebabkan oleh munculnya kontraksi otot-otot uterus, peregangan serviks pada waktu membuka, iskimea rahim (penurunan aliran darah sehingga oksigen mengalami penurunan defisit) akibat kontraksi arteri miometrium ketidaknyamanan dari perubahan serviks dan iskema uterus adalah nyeri viseral yang berlokasi dibawah abdomen menyebar kedaerah lumbar punggung dan menurun kepaha . biasanya nyeri dirasakan pada saat kontraksi saja dan hilang pada saat relaksasi. Nyeri bersifat lokal seperti kram, sensasi sobek dan sensasi panas yang disebabkan karna distensi dan laserasi serviks, vagina dan jaringan perineum. Rasa nyeri apabila tidak ditangani akan menimbulkan rasa takut dan cemas kemudian akan menimbulkan stres serta meningkatkan produksi hormon adrenalin yang mengakibatkan penyempitan pada pembuluh darah dan mengurangi aliran darah yang akan membawa oksigen kerahim sehingga kontraksi mengalami penurunan serta waktu persalinan menjadi panjang. ${ }^{6}$

Seiring kemajuan ilmu teknologi dan ilmu kebidanan, persalinan yang aman bagi ibu dan bayi sudah berkembang . beberapa bentuk yang sudah dikembangkan yaitu persalinan dengan cara SC dan waterbirth. Dengan kedua cara persalinan tersebut ibu cenderung tidak mengalami nyeri pada saat persalinan. Namun dampak perkembangan tersebut terjadi lonjakan biaya yang sangat besar, sehingga salah satu cara untuk mengatasi nyeri pada saat persalinan adalah dengan menerapkan teknik massage. Dua cara teknik massage yang mulai dikembangkan dan di gunakan oleh bidan dan penolong persalinan adalah massage effleurage dan massage counterpressure. ${ }^{7}$

Metode selanjutnya untuk mengurangi nyeri pada saat persalinan adalah dengan cara mendengarkan musik (murothal), murothal merupakan salahsatu musik yang memiliki pengaruh positif bagi pendengarnya, terapi murothal ( mendengarkan bacaan ayat-ayat suci al-Quran) dapat juga mempercepat penyembuhan, hal ini sudah dibuktikan oleh berbagai ahli seperti yang telah dilakukan ahmad al khadi direktur utama islamic institute for edicaton and research di florida amerika serikat, dengan hasil penelitian dengan mendengarkan ayat suci al-Quran memiliki pengaruh yang signifikan dalam menuirunkan ketegangan urat saraf reflektif dan hasil ini tercatat dan terukur secara kuantitatif dan kualitatif oleh alat berbasis komputer. ${ }^{8}$

Berdasarkan studi pendahuluan yang dilakukan oleh peneliti di BPM Bidan M Kota Bogor diperoleh data persalinan yang tercatat pada bulan Januari sampai bulan Maret 2019 sebanyak 74 ibu bersalin, 35 Ibu primigravida dan 39 ibu multigravida. Kasus ibu primigravida pada proses persalinan yaitu ibu selalu merasakan nyeri dan takut pada proses persalinan sehingga menyebabkan rasa nyeri persalinan yang bertambah, dari $10 \mathrm{ibu}$ bersalin primigravida sebanyak 8 orang mengalami nyeri berat, dan 2 orang mengalami nyeri sedang. Ibu bersalin yang mengalami nyeri sebagian besar mengatakan ibu khawatir karena takut tidak bisa mengeluarkan bayinya, takut tidak bisa meneran pada waktunya nanti, dan tidak tahan dengan rasa nyeri.Ibu bersalin yang tidak mengalami nyeri mengatakan bahwa dirinya sedikit tenang karena ada keluarga yang mendampingi. Di klinik tersebut pada ibu yang sedang dalam proses persalinan belum pernah diberikannya terapi non-farmakologi seperti massage effleurage, massage counterpressure dan musik (murothal).

Tujuan dilakukannya penelitian ini yaitu untuk mengetahui Efektifitas massage counterpressure massage effleurage dan murothal terhadap penurunan nyeri persalinan primigravida kala I fase aktif di BPM Bidan M Bogor tahun 2019. Berdasarkan latar belakang diatas maka penulis tertarik untuk meneliti 
tentang "Efektifitas massage counterpressure, massage effleurage dan murothal terhadap penurunan nyeri persalinan primigravida kala I fase aktif di BPM Bidan M Bogor tahun 2019."

\section{Metode}

Penelitian ini menggunakan metode kuantitatif dengan jenis penelitian quasi eksperimen yaitu bentuk penelitian eksperimen yang menggunakan kelompok kontrol tetapi kelompok kontrolnya tidak berfungsi sepenuhnya untuk mengontrol variabel-variabel luar yang dapat mempengaruhinya, pembagian kelompok kontrol dengan kelompok perlakuan tidak dilakukan secara random. ${ }^{9}$ Berdasarkan metode ini diharapkan dapat diketahuinya efektivitas massage counterpressure ,massage effleurage dan murothal terhadap penurunan nyeri persalinan kala I fase aktif primigravida di BPM Bidan M Bogor tahun 2019. Instrumen yang digunakan dalam penelitian ini adalah data primer berupa observasi dengan instrumen penelitian menggunakan lembar Face scale. Pengambilan data responden dilakukan pada ibu bersalin yang mengalami proses persalinan kala I fase aktif di BPM Bidan M.

Populasi penelitian adalah keseluruhan objek penelitian atau objek yang akan diteliti. ${ }^{14}$ Populasi yang digunakan dalam penelitian ini adalah seluruh ibu primigravida dalam proses persalinan kala I fase aktif pada bulan Desmeber-Januari di Bidan Praktik Mandiri Bidan M Tahun 2019 yang berjumlah 30 responden. ${ }^{9}$ Sampel pada penelitian ini adalah seluruh ibu primigravida yang mengalami proses persalinan kala I fase aktif di Bidan Praktik Mandiri M Kota bogor yang berjumlah 30 responden dibagi menjadi 3 kelompok, kelompok 1 sebanyak 10 responden yang diberikan perlakuan massage effleurage, kelompok 2 sebanyak 10 responden yang diberikan perlakuan massage counterpressure dan kelompok ke 3 sebanyak 10 responden yang diberikan terapi musik (murothal). Kemudian dilakukan penelitian untuk satu pasien untuk satu perlakuan.

Teknik pengambilan sampel yang digunakan pada penelitian ini adalah dengan menggunakan Total Sampling. Hakikatnya dari pengambilan sampel secara keseluruhan dari populasi mempunyai kesempatan yang sama sebagai sampel. Analisa data pada penelitian ini dilakukan analisis data univariat dan bivariat. Dalam penelitian ini variabel yang diuji adalah skala berbentuk numerik, maka uji yang digunakan uji-T dependent dengan menggunakan SPSS versi 18. Dengan dasar pengambilan keputusan taraf alfa $5 \%$ dengan nilai $p$-value $\leq 0,05$ maka H0 ditolak artinya ada perbedaan antara variabel independent dan dependent. Jika $p$-value $\geq 0,05$ maka Ha ditolak artinya tidak ada perbedaan antara variabel independent dengan variabel dependen.

\section{Hasil}

Analisis Univariat

Tabel 1 Distribusi Frekuensi Massage Counterpressure, Massage Effleurage, Musik (murothal) pada Ibu Bersalin Kala I Fase Aktif Primigravida di BPM Bidan M.

\begin{tabular}{lccc}
\hline \multicolumn{1}{c}{ Variabel } & Mean & SD & Min-Max \\
\hline Massage Counterpressure & 6,60 & 1,535 & $4-9$ \\
Massage Effleurage & 7,05 & 0,887 & $6-9$ \\
Musik (Murothal) & 6,75 & 1,019 & $5-8$ \\
\hline
\end{tabular}

Sumber: Data Olah SPSS, 2020 
Hasil penelitian yang telah diolah dengan analisis univariat disajikan dalam bentuk tabel distribusi frekuensi antara lain massage counterpressure, massage effleurage, musik (murothal) pada ibu bersalin kala I fase aktif primigravida. Berdasarkan hasil tabel 1, dari analisis terhadap 10 responden yang diteliti, diperoleh hasil mean massage counterpressure pada ibu bersalin kala I fase aktif primigravida yaitu 6,60 dengan standar devisiasi 1,535. Hasil massage counterpressure terendah yaitu 4 dan tertinggi 9. Dari hasil analisis dapat diketahui bahwa mean Massage effleurage pada pada ibu bersalin kala I fase aktif primigravida yaitu 7,05 dengan standar devisiasi 0,887 . Hasil massage effleurage terendah yaitu 6 dan tertinggi 9. Dari hasil analisis dapat diketahui bahwa mean musik (murothal) pada ibu bersalin kala I fase aktif primigravida yaitu 6,75 dengan standar devisiasi 1,019. Hasil musik (murothal) terendah yaitu 5 dan tertinggi 8.

\section{Analisis Bivariat}

Berdasarkan tabel dibawah ini diketahui bahwa efektifitas nyeri terhadap massage counterpressure didapatkan hasil nilai t yaitu 11.759 dengan rata rata nyeri sebelum mendapatkan massage counterpressure yaitu 7.90 sedangkan rata rata yang sudah diberikan massage counterpressure yaitu 5.30. Hasil uji statistik dengan menggunakan Uji Paired T-Test didapatkan nilai Sig (2-tailed) 0.000 pada Alpha 5\% yaitu $0.000<0.05$ yang berarti terdapat efektivitas massage counterpressure terhadap penurunan nyeri pada ibu bersalin primigravida kala I fase aktif. Diketahui bahwa nyeri ibu bersalin yang mendapatkan massage effleurage didapatkan hasil nilai t yaitu 5.014 dengan rata rata nyeri sebelum mendapatkan massage effleurage yaitu 7.50 sedangkan rata rata yang sudah diberikan massage effleurage yaitu 6.60. Hasil uji statistik dengan menggunakan Uji Paired T-Test didapatkan nilai Sig (2tailed) 0.001 pada Alpha $5 \%$ yaitu $0.001<0.05$ yang berarti terdapat efektivitas massage counterpressure terhadap penurunan nyeri pada ibu bersalin primigravida kala I fase aktif.

Diketahui bahwa nyeri ibu bersalin yang mendapatkan musik (murothal)didapatkan hasil nilai t yaitu 3.250 dengan rata rata nyeri sebelum mendapatkan musik (murothal) yaitu 7.20 sedangkan rata rata yang sudah diberikan musik (murothal) yaitu 6.30. Hasil uji statistik dengan menggunakan Uji Paired T-Test didapatkan nilai Sig (2-tailed) 0.010 pada Alpha 5\% yaitu $0.010<0.05$ yang berarti terdapat efektivitas musik (murothal) terhadap penurunan nyeri pada ibu bersalin primigravida kala I fase aktif.

Tabel 1. Distribusi Distribusi Massage Counterpressure, Massage Effleurage, Musik (Murothal) terhadap Penurunan Nyeri Persalinan Primigravida Kala I Fase Aktifdi BPM Bidan M Kota Bogor Tahun 2020

\begin{tabular}{|c|c|c|c|c|c|c|c|}
\hline \multicolumn{2}{|c|}{ Tingkat Nyeri } & \multirow{2}{*}{$\begin{array}{l}\mathbf{N} \\
10\end{array}$} & \multirow{2}{*}{$\begin{array}{c}\text { Mean } \\
7.90\end{array}$} & \multirow{2}{*}{$\begin{array}{c}\begin{array}{c}\text { Standar } \\
\text { Deviasi }\end{array} \\
0.737\end{array}$} & \multirow{2}{*}{$\begin{array}{c}\begin{array}{c}\text { Standar } \\
\text { Eror }\end{array} \\
0.233\end{array}$} & \multirow{3}{*}{$\begin{array}{c}\mathbf{t} \\
11.759\end{array}$} & \multirow{3}{*}{$\begin{array}{l}\begin{array}{l}\text { Sig (2- } \\
\text { tailed) }\end{array} \\
0.000\end{array}$} \\
\hline Massage & Sebelum & & & & & & \\
\hline Counterpressure & Sesudah & 10 & 5.30 & 0.823 & 0.260 & & \\
\hline \multirow{2}{*}{$\begin{array}{l}\text { Masssage } \\
\text { Effleurage }\end{array}$} & Sebelum & 10 & 7.50 & 0.849 & 0.268 & \multirow[b]{2}{*}{5.014} & \multirow[b]{2}{*}{0.001} \\
\hline & Sesudah & 10 & 7.60 & 0699 & 0.221 & & \\
\hline \multirow{2}{*}{ Musik (Murothal) } & Sebelum & 10 & 7.20 & 1.032 & 0.326 & \multirow[b]{2}{*}{3.250} & \multirow[b]{2}{*}{0.010} \\
\hline & Sesudah & 10 & 6.30 & 0.823 & 0.260 & & \\
\hline
\end{tabular}

Sumber : Hasil olah SPSS, 2020 


\section{SIMFISIS Jurnal Kebidanan Indonesia}

Volume 01, Nomor 01, Agustus 2021

\section{Pembahasan}

Beberapa keterbatasan yang ditemukan dalam penelitian ini diantaranya adalah nyeri akibat kontraksi dari persalinan yang membuat ibu kurang fokus dan kurang merespon terhadap arahan yang di intruksikan oleh bidan atau peneliti.

\section{Efektivitas Massage Counterpressure Terhadap Penurunan Nyeri pada Ibu Bersalin Primigravida Kala I Fase Aktif}

Diketahui massage counterpressure terhadap penurunan nyeri pada ibu bersalin primigravida kala I fase aktif di BPM Bidan M kota Bogor Tahun 2019 terhadap 10 responden, diperoleh nilai t yaitu 11.759 dengan nilai rata-rata sebelum diberikan massage counterpressure yaitu 7.90dan sesudah diberikan 5.30. Berdasarkan hasil uji statistik didapatkan nilai $p$-value 0,000 maka nilai $p$-value $<0,05$ artinya terdapat pengaruh massage counterpressur terhadap penurunan nyeri pada ibu bersalin primigravida kala I fase aktif. Massage adalah terapi nyeri yang paling primitif dan menggunakan reflek lembut manusia un tuk menahan, menggosok, meremas bagian tubuh yang nyeri. Counterpressure adalah penekanan secara stabil yang dapat dilakukan oleh pendamping persalinan kedaerah sakral dengan sebuah benda keras (misalnya bola tenis) atau tinju atau tumit tangan Aplikasi counterpressure membantu ibu mengatasi sensasi tekanan internal dan rasa nyeri dibagian bawah punggung. Hal ini sangat membantu ketika ibu mengalami nyeri punggung yang disebabkan oleh tekanan dari oksiput terhadap saraf tulang belakang ketika kepala janin berada dalam posisi posterior. Dengan counterpressure akan mengangkat oksiput menjauh dari saraf ini sehingga membantu rasa nyeri.

Rasa nyeri yang dialami ibu pada persalinan adalah manifestasi dari adanya kontraksi otot rahim dan kontraksi inilah yang menimbulkan rasa sakit pada pinggang, daerah perut dan menjalar ke arah paha. Kontraksi ini menyebabkan adanya pembukaan mulut rahim (serviks) dengan adanya pembukaan serviks ini maka akan terjadi persalinan. Teknik massage counterpressure adalah teknik massage untuk nyeri pinggang persalinan dengan metode non farmakologi (tradisional). Yaitu dengan menekan persyarafan pada daerah nyeri pinggang ibu bersalin. Penggunaan kepalan tangan kepinggang ibu selama 20 menit dengan posisi duduk. Penekanan dilakukan ketika responden mengalami kontraksi uterus (yang menimbulkan nyeri pinggang) pada kala I fase aktif.

Dari hasil penelitian Frestiana erinda yang berjudul "aplikasi tindakan teknik counterpressure terhadap penurunan nyeri pada asuhan keperawatan dengan persalinan kala I fase aktif di ruang VK RSUD SUKAHARDJO 2015" dari hasil penelitian tindakan keperawatan non nonfarmakologi pemberian teknik counterpressure pada persalinan kala I yang dilakukan terjadi penurunan nyeri. Sehingga dapat ditarik kesimpulan bahwa massage counterpressure memberikan pengaruh dalam menurunkan nyeri persalinan.

Hasil penelitian ini juga didukung penelitian yang dilakukan oleh Rejeki, dkk (2013) dengan judul "Tingkat Nyeri Pinggang Kala I Persalinan Melalui Teknik Back-Effleurage dan Counterpressure" hasil penelitiannya tersebut setelah dilakukan tindakan massage dengan teknik counterpressure $\mathrm{d}$ dapatkan hasil yang cukup baik yaitu adanya penurunan tentang nyeri dari sekala nyeri tak tertahankan ke sekala berat, dari nyeri berat kesekala sedang hingga ringan.

Menurut asumsi peneliti, massage counterpressure dapat menurunkan tingkat nyeri pada ibu bersalin primigravida kala I fase aktif, sebagian besar ibu bersalin setelah diberikan massage counterpressure selama 20 menit merasa lebih tenang dan rileks sehingga mengalami penurunan rasa nyeri dan tegang dikarenakan pemijatan atau sentuhan counterpressure dapat memberi pengaruh positif bagi kesejahteraan ibu dan janin dan meningkatkan kualitas pelayanan. 


\section{SIMFISIS Jurnal Kebidanan Indonesia}

Volume 01, Nomor 01, Agustus 2021

\section{Efektivitas Massage Effleurage terhadap Penurunan Nyeri Pada Ibu Bersalin Primigravida Kala I Fase Aktif}

Diketahui massage effleurage terhadap penurunan nyeri pada ibu bersalin primigravida kala I fase aktif di BPM Bidan M kota Bogor Tahun 2019 terhadap 10 responden, diperoleh nilai t yaitu 5.014 dengan nilai rata-rata sebelum diberikan massage effleurage yaitu 7.50dan sesudah diberikan 6.60 . Berdasarkan hasil uji statistik didapatkan nilai $p$-value 0,001 berarti nilai $p$-value $<0,05$ artinya terdapat pengaruh massage effleurage terhadap penurunan nyeripada ibu bersalin primigravida kala I fase aktif.

Massage effleurage adalah (pijat ringan) dan cpunterpressure (penekanan) telah banyak membantu perempuan selama kala I persalinan. Effleurage pada abdomen biasanya digunakan dalam metode lamaze untuk mengurangi nyeri pada persalinan normal. Effleurage merupakan salah satu metode non farmakologis untuk mengurangi nyeri selama persalinan yang terdaftar dalam summary of pain relief measure during labor, dimana pada kala I fase laten (pembukaan 0-3) dan fase aktif (pembukaan 4-7) aktivitas yang bisa dilakukan oleh ibu persalinan adalah efflaurage.

Effleurage adalah pijatan ringan dengan menggunakan jari tangan, biasanya pada perut, seirama dengan pernafasan saat kontraksi.Effleurage dapat dilakukan oleh ibu bersalin sendiri atau pendamping persalinan selama kontraksi berlangsung.Hal ini digunakan untuk mengalihkan perhatian ibu dari nyeri saat kontraksi.Menurut Frainere 1999 effleurage merupakan aplikasi dari gate control theory.Teknikteknik yang dapat membantu mekanisme gerbang adalah stimulasi kulit, distraksi (pengalihan fokus nyeri) dan mengurangi kecemasan. Peranan effleurage digunakan untuk membantu ibu distraksi dan mengurangi nyeri.

Dari hasil penelitian priharyanti wulandari tahun 2018 tentang "Pengaruh massage effleurage terhadap pengurangan tingkat nyeri persalinan kala I fase aktif pada primigravida di ruang bougenville RSUD Tugurejo semarang" didapatkan diketahui dari 23 responden yang mengalami penurunan nyeri yaitu 19 dan yang nyerinya tetap adalah 4 . rata rata tingkat nyeri persalinan sebelum massage effleurage yaitu 3,78 (nyeri berat) dan rata rata nyeri persalinan sesudah massage effelurage 2,96 (nyeri sedang) nilai $p$-value $=0.000$ yang berarti lebih kecil dari $0.05(0.000<0.05)$. maka hasil tersebut menunjukan bahwa dengan dilakukannya massage effleurage pada ibu primigravida kala I fase aktif memberikan pengaruh terhadap pengurangan tingkat nyeri persalinan.

Berdasarkan hasil penelitian ini, maka peneliti berasumsi terdapat pengaruh Massage Effleurage terhadap penurunan nyeri pada ibu bersalin primigravida kala I fase aktif. Sebagian besar ibu bersalin yang mengalami nyeri setelah diberikan massage effleurage tersebut, tingkat nyeri pada ibu bersalin mengalami penurunan, sehingga ibu merasa tenang dan nyaman dengan dilakukan massage effleurage tersebut.

\section{Efektivitas Musik (murothal) terhadap Penurunan Nyeri pada Ibu Bersalin Primigravida pada Kala I Fase Aktif}

Diketahui musik (murothal) terhadap penurunan nyeri pada ibu bersalin primigravida kala I fase aktif di BPM Bidan M kota Bogor Tahun 2019 terhadap 10 responden, diperoleh nilai t yaitu 3.250dengan nilai rata-rata sebelum diberikan musik (murothal) yaitu 7.20dan sesudah diberikan 6.30. Berdasarkan hasil uji statistik didapatkan nilai $p$-value 0,010 berarti nilai $p$-value $<0,05$ artinya terdapat pengaruh pernafasan diafragma terhadap penurunan nyeri pada ibu bersalin primigravida kala I fase aktif. Musik, rekaman atau secara live, dapat memberikan kesenangan, meningkatkan relaksasi dan meningkatkan semangat selama persalinan, sehingga mengurangi tingkat tingkat stres pada perempuan, kecemasan dan persepsi nyeri.Hal ini dapat digunakan untuk meningkatkan relaksasi pada awal 
persalinan dan untuk merangsang pergerakan untuk kemajuan persalinan. Musik dapat membantu menciptakan suasana yang lebih santai diruang persalinan, yang mengarahkan pada pendekatan yang lebih santai oleh penyedia layanan kesehatan pernafasan diafragma.

Hasil penlitian ini sejalan dengan penelitian lilin turlina, dkk 2017 tentang "Pengaruh Terapi Murothal Al-Quran terhadap Penurunan Intensitas Nyeri Persalinan Kala 1 Fase Aktif" yang menyatakan bahwa terdap pengaruh pemberian terapi murottahal al-quran terhadap penurunan intensitas nyeri kala 1 di BPM Hj. Yumamik, Amd.Keb. hasil ini ditunjukan bahwa nilai $p=0.001$ $(<0.05)$ yang berarti ada pengaruh pemberian terapi murothal terhadap penurunan intensitas nyeri kala I fase aktif. Hal ini didukung teori yang menyatakan bahwa dengan mendengarkan murothal maka rasa nyeri yang dirasakan oleh ibu berkurang karena dengan murothal akan terjadi perubahan alur alur listrik di otot, perubahan sirkulasi darah, perubahan detak jantung dan kadar darah pada kulit.

Berdasarkan hasil penelitian ini, maka peneliti berasumsi terdapat pengaruh musik (murothal) terhadap penurunan nyeri persalinan kala I fase aktif primigravida. Selain ituh dengan murothal dapat merangsang pergerakan untuk kemajuan persalinan.murothal juga dapat menciptakan suasana yang lebih santai d ruang persalinan.

\section{Kesimpulan}

Berdasarkan hasil penelitian, maka dapat ditarik kesimpulan bahwa ada pengaruh massage counterpressure, massage effleurage dan musik (murothal) terhadap penurunan nyeri persalinan pada ibu bersalin primigravida kala I fase aktif. Perlakuan yang sangat berpengaruh terhadap nyeri ibu bersalin primigravida yaitu terdapat pada variabel massage counterpressure. Hal ini disebabkan karena massage counterpressure merupakan teknik yang paling efektif untuk menurunkan nyeri persalinan karena tekanan yang dilakukan membuat ibu lebih rileks.

Bagi BPM Bidan M Bogor diharapkan Diharapkan lebih meningkatkan pelayanan asuhan sayang ibu pada ibu bersalin serta mampu menerapkan pemberian massage counterpressure pada ibu bersalin untuk mengurangi nyeri persalinan, dan memberikan edukasi kepada ibu atau keluarga tentang massage counterpressure, bahwa dengan dilakukan massage counterpressure nyeri ibu akan berkurang dan ibu tenang dalam menjalani persalinan tersebut dan meningkatkan kualitas pelayanan. Bagi Institusi Pendidikan, dapat menjadi referensi dalam kepustakaan mengenai upaya penurunan nyeri pada ibu bersalin. Bagi peneliti selanjutnya diharapkan dapat mengembangkan penelitian tersebut dengan menggunakan metodepenelitian dengan menggunakan variabel variabel tersebut lebih lanjut. Bagi peneliti yang ingin mengembangkan penelitian yang sama diharapkan dapat lebih baik dan memiliki lebih banyak sumber referensi yang digunakan dan referensi terbaru.

\section{Konflik Kepentingan}

Menyatakan bahwa penelitian ini independen dari konflik kepentingan individu dan organisasi

\section{Ucapan Terima Kasih}

Terimakasih kepada semua responden dan semua pihak yang mendukung penelitian ini.

\section{Pendanaan}

Sumber pribadi. 


\section{References}

1. Irnawati. Tetap tersenyum saat melahirkan, yogyakarta: Media pressindo. 2014.

2. Materniti,dainty,dkk.asuhan kebidanan persalinan.jakarta: binarupa aksara. 2016

3. World Helath Organization (WHO), UNICEF, UNFPA, The Word Bank, Trend in Maternal Mortaliti, Ganeva : Word Health Organization, 2014.

4. Badan pusat statistik provinsi jawa barat 2014.

5. Indrayani, djami moudy emma unaria. Asuhan Persalinan Normal dan Bayi Baru Lahir.Jakarta:Trans Info Media. 2013.

6. Irnawati.Tetap Tersenyum Saat Melahirkan.yogyakarta.Media Pressindo. 2014.

7. Riska aprilia wardani.Jurnal keperawatan dan kebidanan.

8. Notoatmodjo Soekidjo. Metodologi Penelitian Kesehatan. Jakarta: Rineka Cipta. Notoatmodjo, S. (2012). Metodologi Penelitian Kesehatan. Jakarta: Rineka Cipta.

9. Bidan prada.jurnal kebidanan.vol.7 no.1. edisi juni.hal 119-129. 2016.

10. Irham M, Susaldi S. Pengaruh Terapi Serum Iron Injeksi terhadap Peningkatan Nilai Hemoglobin Ibu Hamil dengan Anemia. Jurnal Kesehatan Pertiwi. 2019.

11. Hidayat,A. Aziz Alimul.Metode penelitian Kesehatan Paradigma Kuantitatif. Surabaya: Kelapa Pariwara. 2011.

12. Yosali MA, Sugesti R. Beberapa Faktor yang Berpengaruh terhadap Pencegahan Puerperium Infections. Jurnal Ilmiah Kebidanan Indonesia. 2018;8(01):8-21. 